\title{
EXTENDED LIFE ALUMINIDE FUEL FOR UNIVERSITY RESEARCH REACTORS
}

Lowell G. Miller

Keith R. Brown

Joseph M. Beeston

Dave M. McGinty

Published December 1983

EG\&G Idaho, Inc.

Idaho Falls, Idaho 83415

Prepared for the

U.S. Department of Energy

Idaho Operations office

Under DOE Contract No. DE-ACO7-76ID01570

This document is

PUBLICLY RELEASABLE

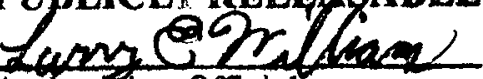

Authorizing Ofricial

Date: $10 / 11 / 2006$
DISTRIBUTION OF THIS DOCUMENT is 


\section{DISCLAIMER}

This report was prepared as an account of work sponsored by an agency of the United States Government. Neither the United States Government nor any agency Thereof, nor any of their employees, makes any warranty, express or implied, or assumes any legal liability or responsibility for the accuracy, completeness, or usefulness of any information, apparatus, product, or process disclosed, or represents that its use would not infringe privately owned rights. Reference herein to any specific commercial product, process, or service by trade name, trademark, manufacturer, or otherwise does not necessarily constitute or imply its endorsement, recommendation, or favoring by the United States Government or any agency thereof. The views and opinions of authors expressed herein do not necessarily state or reflect those of the United States Government or any agency thereof. 


\section{DISCLAIMER}

Portions of this document may be illegible in electronic image products. Images are produced from the best available original document. 
EG\&G Idaho/Department of Energy, University of Missouri, and Massachusetts Institute of Technology are conducting a test program to determine if the fuel loading and burnup limits for fuel elements in university research reactors can be safely increased beyond the limits presently allowed by reactor licensing restrictions. For the tests, 30 fuel plates were constructed to a maximum fuel loading which could be produced on a commercial basis and to contain a maximum boron content as used in the Advanced Test Reactor at the Idaho National Engineering Laboratory to reduce initial reactor reactivity. $A_{U A}$ fuel matrix was used to gain higher uranium content. The test program planned for the fuel plates to be irradiated to a $3.3 \times 10^{21} \mathrm{fissions} / \mathrm{cm}^{3}$ average burnup ( $45 \%$ of U-235 for the 50 vol\% fuel plate cores). This would be twice the burnup presently allowed in the university reactors. Irradiation performance of the heavy loaded fuel plates has been good at burnups exceeding $2.3 \times 10^{21}$ fissions $/ \mathrm{cm}^{3}$, with one fuel plate reaching a peak burnup of about $3 \times 10^{21}$ fissions $/ \mathrm{cm}^{3}$. Three fuel plates failed, however, during the irradiation, and are undergoing destructive analysis. Corrosion pitting occurred in cladding of both $\mathrm{UAl}_{2}$ and $\mathrm{UAl}_{3}$ fuel plates. Some plates appear to be more resistant to corrosion pitting than others. Localized swelling in high fuel loaded plates also is being investigated as a possible failure mode. 


\section{CONTENTS}

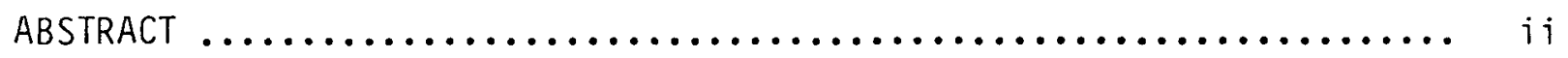

BACKGROUND $\ldots \ldots \ldots \ldots \ldots \ldots \ldots \ldots \ldots \ldots \ldots \ldots \ldots \ldots \ldots \ldots \ldots \ldots \ldots \ldots \ldots$

UAl 2 VERSUS UAI 3 FUEL CORE MATRIX $\ldots \ldots \ldots \ldots \ldots \ldots \ldots \ldots \ldots \ldots \ldots \ldots$

FUEL PLATE DESIGN $\ldots \ldots \ldots \ldots \ldots \ldots \ldots \ldots \ldots \ldots \ldots \ldots \ldots \ldots \ldots \ldots \ldots \ldots$

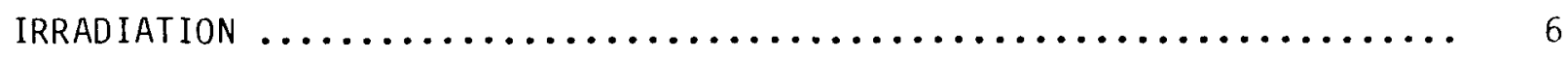

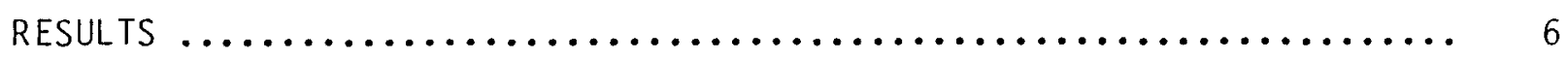

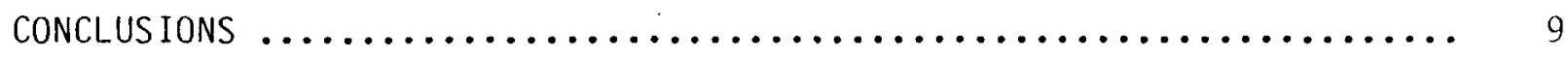

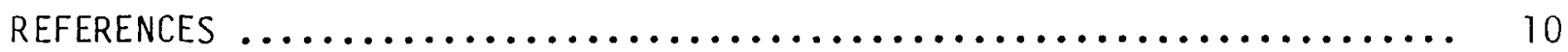


EXTENDED LIFE ALUMINIDE FUEL FOR

UNIVERSITY RESEARCH REACTORS

BACKGROUND

The Reduced Enrichment Research Test Reactor (RERTR) Program seeks to reduce enrichment levels in most research reactors by coupling an enrichment reduction with increased uranium weight over present loadings.

Research reactors at several universities, however, cannot continue present performance levels with reduced fissionable atom concentration. Fuel elements for these reactors are provided under the university fuel procurement Test, Research, and Training Reactor (TRTR) Program by the Idaho National Engineering Laboratory (INEL) as directed by the United States Department of Energy--Idaho Office (DOE-ID).

As the prices of fuel fabricating, shipping, and reprocessing continue to rise at rapid rates, researchers look for alternate methods to keep their reactor fuel costs within limited funding. Extending fuel element lifetimes without jeopardizing reactor safety can reduce fuel costs by up to a factor of two. But to gain this factor, fuel plates must be tested to the higher burnup limits to verify the fuel plate burnup performance.

Early in 1980, support for a heavily loaded, high-burnup fuel plate irradiation test program was received from the University of Missouri and the Massachusetts Institute of Technology (MIT). This support is a result of the fuel cost savings to be realized from high burnup of high-fuel-loaded plates in their research reactors. A program plan was completed, and 30 fuel plates containing 40,45 , and 50 vol $^{2} \mathrm{UAl}_{2}$ and $50 \mathrm{vol}^{2} \mathrm{UAl}_{3}$ core materials were fabricated. The $\mathrm{UAl}_{3}$ plates were included as a baseline case.

The test program was started in July 1981. When the test program is completed, results are expected to provide the University of Missouri and the MIT with technical justification for using high-burnup, high-fuel-loaded long-life aluminide fuel elements. Fuel cost savings at Missouri University Research Reactor (MURR) alone would be about $\$ 250,000$ per year. Results of 
these tests could also be used by the RERTR Program to justify the higher uranium loadings in fuel plates in the form of $\mathrm{UAl}_{2}$.

UAI $1_{2}$ VERSUS UAT ${ }_{3}$ FUEL CORE MATRIX

Considerable radiation testing has been done with UA $]_{x}$ powder in which $U A I_{3}$ is the principal crystalline constituent; and several years of operational experience in the Advanced Test Reactor (ATR) at the INEL and other reactors has justified the MIT reactor (MITR) and MURR maximum burnup of $1.8 \times 10^{21}$ fissions $/ \mathrm{cm}^{3}$. The ATR burnup limit has been extended in steps to a fission density of $2.3 \times 10^{21}$ fissions $/ \mathrm{cm}^{3}$ in a $\mathrm{UAl}_{3}$. core. A report by Beeston et al. 1 indicates that an extension to $2.7 \times 10^{21}$ fissions $/ \mathrm{cm}^{3}$ of core burnup is possible.

The fuel powder composition which is predominantly UA $1_{3}$ was originally chosen since the powder can be prepared in air. UA1 2 powder is more pyrophoric than $\mathrm{UA}_{3}$. Some work has been done by Dienst et a $1^{2}$ at Karlsruhe on irradiation behavior of $U A I_{2}-A I$ and $U A I_{3}-A I$ dispersion fuels for thermal high-flux reactors. Although they did not study the range of our required fuel loading, data strongly suggest that for high-loaded, high-burnup fuel plates, $U A I_{2}-A 1$ dispersion performs considerably better than $U \mathrm{Al}_{3}-\mathrm{Al}$.

It is shown in Figure 1 that higher total uranium concentration can be achieved with UAl 2 than with UAI 3 for the same weight or the same volume percent. However, UAI $x$ is a brittle constituent so that some limit on the core uranium content is required for rolling fabrication. The uranium content of $\mathrm{UAl}_{2}$ is $81.0 \mathrm{wt} \%$, and that of $\mathrm{UAl}_{3}$ is $74 \mathrm{wt} \%$.

If 50 vol\% of $U A I_{x}$ were taken as a limit of brittle constituent $U A 1_{x}$, then from $F$ igure 1 , the uranium concentration using $U A 1_{3}$ would be $2.53 \mathrm{~g} / \mathrm{cm}^{3}$ of core, and using $U A 1_{2}$ would be $3.31 \mathrm{~g} / \mathrm{cm}^{3}$ of core, and the corresponding core weight percent of $U \mathrm{UI}_{3}$ and $U \mathrm{UA}_{2}$ would be 72 and 75 , respectively. Thus, using $\mathrm{UAl}_{3}$, the core would be mostly brittle constituent (some of the volume is voids), while using UAI, more ductile aluminum can be present. A rolling test program at Atomics International 


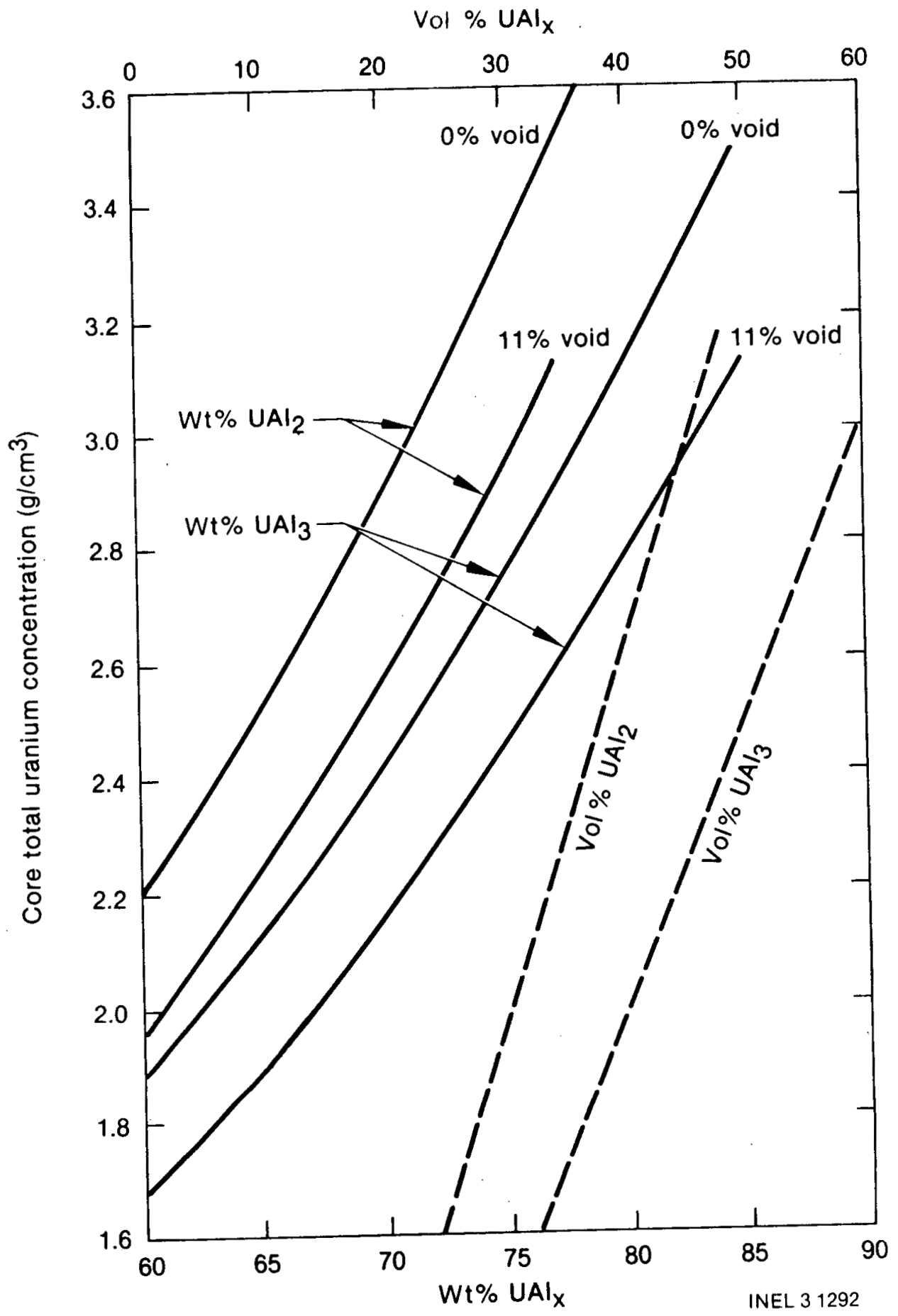

Figure 1. Uranium content versus weight or volume percent $U A 1_{X}$. 
$(\mathrm{AI})^{3}$ indicated current technology can be used to produce quality fue 1 plates on a production line basis with fuel cores containing up to 50 vol\% UAT $\mathrm{x}$.

The MURR and MITR fuel plates, however, are currently being made with a uranium content of $21.6 \mathrm{~g} / \mathrm{cm}^{3}$, or about half the possible fuel content limit. Therefore, by using the recent data from the AI rolling tests and $U A 1_{2}$ powder, the uranium content in the plates can be increased from the present value by about $100 \%$, depending on void content. This increase will be important where long-life elements are desired, although some reactors at present may not be able to take full advantage of the full $100 \%$ increase due to excess reactivity limitations even with a high boron loading.

Although $U \mathrm{Al}_{2}$ is more pyrophoric than $U \mathrm{Al}_{3}$, current fabrication techniques are compatible with either dispersion. The glove boxes use an argon atmosphere with a maximum oxygen content of $4 \%$.

\section{FUEL PLATE DESIGN}

Fuel plate dimensions were selected to fit the ATR I-hole configuration and to provide the plate area required for testing. Thickness of plates and cores and plate construction methods were selected to match the MURR and ATR fuel. Extrapolation of the test data to a 1.524-mm (0.060-in.) plate will provide MIT with the required supporting data for extended fuel burnup in the MITR. Table 1 indicates the test specifications.

The finished plates measure $25.4 \pm 0.127 \times 317.5 \pm 0.762 \times 1.27 \pm$ $0.025 \mathrm{~mm}(1.000 \pm 0.005 \times 12.50 \pm 0.030 \times 0.050 \pm 0.001 \mathrm{in.})$. The fuel core dimensions are $220.32 \times 266.7 \times 0.508 \mathrm{~mm}(0.8 \times 10.5 \times 0.02$ in.). A 9.525-mm (3/8-in.) hole centered in the top end of each plate provides a means for individual plate removal in the canal or hot cell.

The UAI powder was prepared, and the fuel plates were fabricated by AI. The U-235 enrichment was $93.0 \pm 1.0 \%$ for all batches. The metal impurities were less than $0.3 \%$, with no individual impurity exceeding $600 \mathrm{ppm}$. No free metallic uranium was present in any powder sample. 
TABLE 1. TEST SPECIFICATIONS

\begin{tabular}{|c|c|c|c|}
\hline Compound & $\left(\mathrm{g} / \mathrm{cm}^{3}\right)^{\mathrm{a}}$ & $\begin{array}{l}\quad U A 1_{x} \\
(\text { core vol\%) }\end{array}$ & $\begin{array}{c}\text { Estimated } \\
\text { Maximum } \\
\text { Burnup } \\
\text { (fission/cm } 3 \text { ) } \\
\end{array}$ \\
\hline $\mathrm{UA}_{2}$ & 2.51 & 40 & $2.9 \times 10^{21}$ \\
\hline UA ${ }_{2} 2$ & 2.82 & 45 & $3.0 \times 19^{21}$ \\
\hline$U A]_{2}$ & 3.13 & 50 & $3.3 \times 10^{21}$ \\
\hline$U A I_{3}$ & 2.22 & 50 & $2.7 \times 10^{21}$ \\
\hline $\begin{array}{l}\text { These are } \\
\text { to other cryst }\end{array}$ & $\begin{array}{l}\text { al value } \\
\text { rms of U/ }\end{array}$ & \multicolumn{2}{|c|}{$\begin{array}{l}\text { Expected values may differ slightly due } \\
\text { in the core material. }\end{array}$} \\
\hline
\end{tabular}


Nondestructive testing (NDT) inspections for nonbond and minimum cladding thickness met the acceptance criteria of the ATR Fuel Element Specification IN-F-9-ATR, Rev. 5.

\section{IRRADIATION}

Irradiation was begun in the ATR I-9 facility in July 1981, and has continued intermittently since then. The thermal flux in the facility varies between 3 and $7 \times 10^{13} \mathrm{n} / \mathrm{cm}^{2} \mathrm{~s}$. The peak gamma heat in the facility of $1.55 \mathrm{~W} / \mathrm{g}$ was used with corrosion film estimates in the MACABRE computer code to calculate maximum fuel plate temperatures versus operating time. The maximum nominal and 2 o plate temperatures were 395 and $407 \mathrm{~K}$, respectively, and decreased with operating time.

Neutron flux and burnup calculations were made with the PDQ neutron diffusion-depletion program through the irradiation history of the fuel plates. Two-dimensional XY and RZ-4 energy group PDQ problems were developed to model the tests. In the burnup calculation for each test cycle, a correction factor was applied so that the calculated thermal neutron flux matched the measured value obtained from the flux wire monitors, which were $p l a c e d$ in the test and removed after each test cycle.

\section{RESULTS}

Irradiation of 19 plates to burnups indicated in Figure 2 have been conducted. The cumulative average and peak fission densities are given in Table 2. In general, the performance has been good. One plate in the $50 \mathrm{vo}_{1 \%} \mathrm{UAl}_{2}$ composition has reached a burnup of about $3 \times 10^{21} \mathrm{fis}$ sions $/ \mathrm{cm}^{3}$ ( $57.8 \%$ of $\mathrm{U}-235$ burned up). The reference $50 \mathrm{vol}^{\mathrm{N}} \mathrm{UAl}_{3}$ plates are also performing well, but at lower burnup because of their location in the irradiation facility. It is a reference fuel only in the sense of proven fabrication techniques, but not in the sense of proven irradiation burnup behavior. Most ATR U-Al dispersion fuel plates have been fabricated at about 32 vo $1 \% \mathrm{UAI}_{\mathrm{x}}$. From Figure 2 , it can be seen that the 40 vol\% UAl, is performing well with a peak burnup of about $2.5 \times 10^{21}$ fissions $\mathrm{cm}^{3}$ of core which compares with most ATR UAT 


\section{Fuel plate}

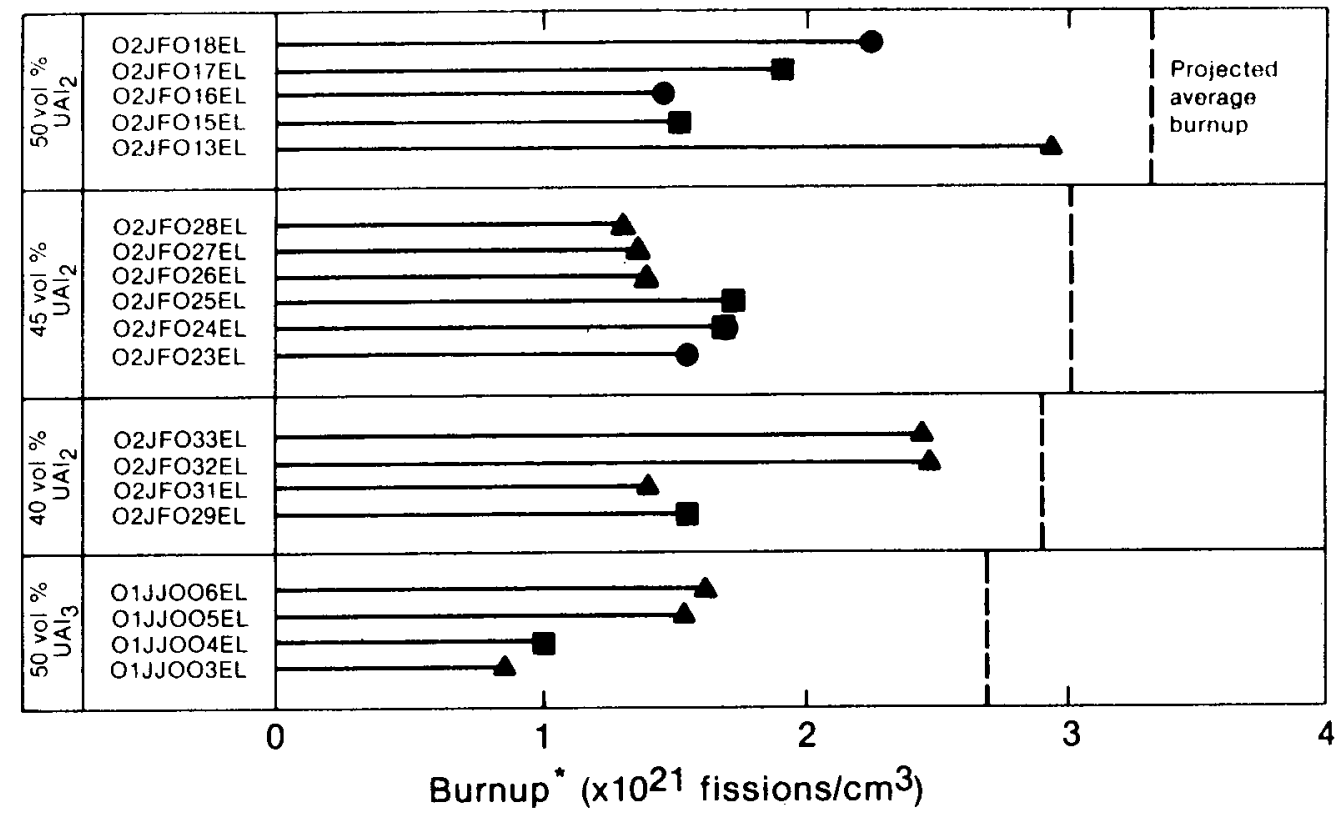

- Failed plate

"Average plate burnup about $75 \%$ of peak.

- Removed because of pitting, etc.

$\Delta$ Continuing in test

INEL 31293

Figure 2. Fuel plate peak burnup levels.

TABLE 2. RANGES OF FUEL PLATE BURNUP

\begin{tabular}{|c|c|c|}
\hline Composition & $\begin{array}{l}\text { Cumulative Average } \\
\text { Fission Density } \\
\left(\times 10^{21} \text { fissions } / \mathrm{cm}^{3}\right) \\
\end{array}$ & $\begin{array}{l}\text { Cumulative Peak } \\
\text { Fission Density } \\
\left(\times 10^{21} \text { fissions } / \mathrm{cm}^{3}\right) \\
\end{array}$ \\
\hline $\begin{array}{l}40 \text { vol\% } \\
\text { UA } 1_{2}\end{array}$ & 1.01 to 1.89 & 1.39 to 2.49 \\
\hline $\begin{array}{l}45 \text { vol\% } \\
\text { UAT } 2\end{array}$ & 0.95 to 1.25 & 1.31 to 1.75 \\
\hline $\begin{array}{l}50 \text { vol\% } \\
\text { UAl } 2\end{array}$ & 1.12 to 2.23 & 1.45 to 2.95 \\
\hline $\begin{array}{l}50 \text { vol\% } \\
\text { UAl } 3\end{array}$ & 0.73 to 1.43 & 1.02 to 1.61 \\
\hline
\end{tabular}


dispersion fuel plates with a burnup limit of $2.3 \times 10^{21}$ fissions $/ \mathrm{cm}^{3}$. The 40 vol\% UAl ${ }_{2}-\mathrm{Al}$ dispersion has achieved an irradiation behavior significant in two respects: (a) it has surpassed the burnup limit of $2.3 \times 10^{21}$ fissions $/ \mathrm{cm}^{3}$ and is approaching the experimentally achieved fission density of $2.7 \times 10^{21} \mathrm{fissions} / \mathrm{cm}^{3}$ (in ATR), but is below the experimentally achieved fission density of $3.4 \times 10^{21}$ fissions $/ \mathrm{cm}^{3}$ (reported by Dienst ${ }^{2}$ ) and the test program target fission density ${ }^{4}$ of $3.3 \times 10^{21}$ fissions $/ \mathrm{cm}^{3}$; and (b) the 40 vol\% composition $\left(2.5 \mathrm{~g} / \mathrm{cm}^{3}\right)$ has a higher uranium fuel loading than ATR U-Al dispersion fuel plates.

The irradiation achievement of the $40 \mathrm{vol}^{\mathrm{U}} \mathrm{UAl}_{2}$ can also be applied to the 50 vol\% $\mathrm{UAI}_{2}$, and at lower fission density for the $45 \mathrm{vol}^{\mathrm{V}} \mathrm{UA} \mathrm{I}_{2}$, except that two plate failures occurred in the $50 \mathrm{vol}^{\mathrm{U}} \mathrm{UAl}_{2}$ and one in the 45 vol\% UAL 2 (see Figure 2). The cause of these plate failures is being investigated, but appears to be attributable to one of two possible failure modes: (a) swelling of nonbonded or large void regions and (b) corrosion pit perforation of the fuel cladding. Two other unlikely failure modes are (a) swelling of $U A I_{x}$ fuel from fission gas production and (b) restricted cooling to the plate surface with overheating. Swelling of $U A 1_{x}$ fuel is unlikely because:

1. The blister temperature is probably still high ${ }^{l}$ at $>720 \mathrm{~K}$. Measurements on the three failed plates (Figure 2) also gave high blister temperatures, $>720 \mathrm{~K}$, which indicates accommodation of the fission gas in small nuclei or within the $U A l_{x}$ fuel structure.

2. $U A 1_{x}$ fuel has been irradiated to higher fission density ${ }^{2}$ without indication of general fission gas swelling.

Restricted cooling of the plate surface is unlikely because: (a) no evidence was seen of restricted channels except for corrosion products, and (b) the maximum 2 o plate temperature of $407 \mathrm{~K}$ gives such a high margin for this failure mode, as compared with the blister temperature of $720 \mathrm{~K}$.

Evidence for the first failure mode has not been observed. Swelling of nonbonded or large void regions should produce localized swelling of the 
fuel plate. Localized swelled regions have been observed, but these were associated with perforation by pitting. Thickness measurements were made on two plates after reactor Cycle 58D-1. Nine measurements of thickness over the length of the surface of one plate resulted in a thickness increase of $5 \%$, based on a core thickness of $0.508 \mathrm{~mm}$ ( $0.020 \mathrm{in.)}$ (a volume swelling of 15\%), and on the second plate the result was a thickness increase of $4.6 \%$ (14 vol\%). This volume swelling for the peak fission density along the edge of the fuel region is about the same as observed in Reference 2 at about the same fission density and plate temperature of $453 \mathrm{~K}$.

Corrosion pitting in the surface of the fuel cladding has also been observed. After reactor Cycle 58D-1, an oxide prefilm was applied to the fuel plate cladding surface to reduce the incidence of pitting. However, the effect was minor. After further irradiation, the old plates had fewer corrosion spots (pits) than the prefilmed replacement plates. By comparison of the number of corrosion pits on the prefilmed replacement plates with the old plates, the prefilming has not reduced the corrosion pitting problem. As indicated in Figure 2, five plates have not developed corrosion pits and have continued for all test periods; hence, some plates are more resistant to formation of corrosion pits than others.

\section{CONCLUSIONS}

1. The irradiation performance of $U A_{2}$ fuel plates with higher volume percent of $U \mathrm{Ul}_{2}$ than conventional ATR fuel plates (32 vol\% UA $1_{X}$ ) has been good.

2. An increase in the burnup limit beyond $2.3 \times 10^{21} \mathrm{fission} / \mathrm{cm}^{3}$ of core for higher fuel loaded plates than conventional appears to be feasible without major risk.

3. Corrosion pitting of high-fuel-loaded plates as well as conventional plates is an important failure mode.

4. Some plates seem to be more resistant to corrosion pitting than others. 


\section{REFERENCES}

1. J. M. Beeston et al., "Development and Irradiation Performance of Uranium Aluminide Fuels in Test Reactors," Nuclear Tech.,2 49, 1980, pp. 136-149.

2. W. Dienst, S. Nazare', F. Thummer, "Irradiation Behavior of UAl $-A T$ Dispersion Fuels for Thermal High Flux Reactors," J. Nucl. Materials, 64, 1977, pp. 1-13.

3. D. Atkins, Results and Evaluation of Producibility Studies Using UAl for Low Enrichment Fue PTaEes, N275TR00000T, RockweTT Internationat, $197 \overline{9}$.

4. L. G. Miller and J. M. Beeston, Fuel Plate and Fusion Insulator Irradiation Test Program, EGG-FT-5273, November 1980. 